\title{
A DESCRIPTIVE STUDY OF THE PHONOLOGY OF GUREZI SHINA*
}

\author{
MUSAVIR AHMED \\ Department of Linguistics, University of Kashmir \\ Srinagar, Kashmir, J\&K, 190006, India \\ e-mail: ahmed.musavir@gmail.com
}

\begin{abstract}
Gurezi Shina is a lesser known variety of Shina language being spoken by the inhabitants of Gurez, a remote northern valley in the Indian state of Jammu and Kashmir. The paper reports a part of the findings of a major research study, undertaken for the description and documentation of this language with an aim to substantiate efforts for its preservation. The paper is a first attempt to present the sound system of Gurezi Shina in detail; the vowels and consonants of the language have been identified through minimal pair of words. Distribution of sounds in words are given in detail. An introduction to the linguistic classification of the language has also been presented. The data for the study have been collected during several field visits to Gurez valley.
\end{abstract}

Key words: Shina, Dardic languages, Nuristani languages, phonology.

\section{The Language}

Shina, pronounced locally as / Jinãã/ or / Jinããa is the language of the people scattered over a vast mountainous region stretching from northern areas of Jammu and Kashmir in the east through the territories in Northwest Province of Pakistan into the northeastern parts of Afghanistan. According to Kohistani and Schmidt (2006, p. 137) the Shina speaking areas under the administration of Pakistan include Gilgit, lower Hunza, Tangir-Darel, Astor and Chilas valleys and areas in Indus Kohistan, while India administers the Shina speaking areas in the Neelam (Kishenganga) drainage, the Gurez and Tiliel valleys, the Drass plain and Ladakh. More specifically, Shina is spoken in Gurez valley of District Bandipora of Kashmir Division and Drass Area of Kargil Dis-

*Acknowledgement: The author would like to thank the University Grants Commission, New Delhi for financially supporting the Major Research Project "Description, Documentation and Preservation of Shina". 
trict in Ladakh Division in the northern state of Jammu and Kashmir of India. The two varieties of Shina spoken in Jammu and Kashmir have been named after the regions these are being spoken in: Gurezi (Gurez) and Drasi (Dras). Sometimes scholars refer to a third variety called Tileili Shina, spoken in the Tileil valley of Gurez in Bandipora District of Jammu and Kashmir. However, Tiliel being part of the broader valley of Gurez, it is mostly subsumed under the variety Gurezi.

Radloff (1999, p. 3) puts the number of Shina speakers in Pakistan at around 500,000. Kohistani and Schmidt (2006, p. 139) citing various sources report that the total number of Shina speakers in Pakistan are 1,123,874, including those who have migrated to other areas of Pakistan. The exact number of speakers in Jammu and Kashmir is difficult to establish owing to the lack of a language census of the state. The population of Gurez, Jammu and Kashmir, as per the 2011 census of India was 34,390 , out of which approximately some 30,000 are Shina native speakers. The rest are native Kashmiri speakers.

\section{Linguistic Classification}

The first linguistic classification of the languages of the northern territories from Kashmir to the northern parts of Afghanistan was offered by George A. Grierson in his monumental work Linguistic Survey of India published in the first decade of the last century. The languages named by Grierson as 'Dardic' included Kashmiri and Shina.

According to Grierson $(1919$, p. 2) Dardic, as a separate branch of Indo-Iranian, comprises three groups: (1) the Kafir group; (2) the Khowar group; (3) the Dard group proper (including Shina, Kashmiri and Kohistani).

However, the linguistic basis of Grierson's classification of Dardic languages has been challenged following the works of Georg Morgenstierne (1926; 1932; 1961). In the first instance, Morgenstierne (1926) dissociated the languages of the Kafir group $^{1}$ from the Dardic family of languages. Subsequent works of Morgenstierne were able to establish that the languages classified by Grierson as Dardic, except the Kafir group, are in fact Indo-Aryan languages:

"there is not a single common feature distinguishing Dardic, as a whole, from the rest of the IA languages ... Dardic is simply a convenient term to denote a bundle of aberrant IA hill languages, which in their relative isolation have been in a varying degree sheltered against the expanding influence of IA midland (Madhyadesha) innovations being left free to develop on their own" (Morgenstierne 1961, p. 139, cited in Petersen, 2006, p. 22).

Grierson's use of the term Dardic as an umbrella term for the languages spoken in the mountainous belt spanning from Kashmir to northern Afghanistan has been attributed to Leitner's $(1880 ; 1893)$ use of the term Dardistan.

${ }^{1}$ These languages have been renamed by Strand (1973) as Nuristani languages. 
"Leitner's Dardistan, in its broadest sense, became the basis for the classification of the languages in the north-west of Indo-Aryan (IA) linguistic area (which includes the present day Afghanistan, northern Pakistan and Kashmir)" (Mock 1997).

Subsequent linguistic works, some of them based on extensive field work in the area, further substantiated Morgenstierne's viewpoint. Prominent among these works are Fussmann (1972), Strand (1973), Masica (1991), Radloff (1992), Bashir (2003), Zoller (2005), Schmidt and Kohistani (2008) and Liljegren (2008).

According to Bashir (2003, p. 822) "the designation 'Dardic' neither implies ethnic unity among the speakers of these languages nor that they can all be traced to a single Stammbaum-model node". Earlier Strand (1973, p. 298), following the footsteps of Morgenstierne, has gone one step further in suggesting that the term 'Dardic' should be abandoned from usage in favour of the more appropriate name Northwest Indo-Aryan languages.

However, a certain amount of uniformity among these languages seems to be sufficiently strong enough to prevent the scholars from not using the term Dardic, although it may be correct only in the geographical sense. "Dardic is a geographical cover term for those Northwest Indo-Aryan languages which because of their isolation in the mountains of Hindu Kush, Swat and Indus Kohistan, the Karakorams and Western Himalayas have retained ancient and developed new characteristics different from the IA languages of the Indo-Gangetic Plain” (Bashir 2003, pp. 821-822).

As far the uniformity among these languages is concerned, she notes that these "languages on the whole underwent fewer of the major MIA phonological and morphological developments than plains IA" (Bashir 2003, pp. 821-822).

Radloff refers to the languages "clustered in the mountainous areas of northern Pakistan and stretch into Kashmir on the east and Afghanistan on the west" as Dardic (Radloff 1999, p. 4).

Zoller also makes use of the term Dardic and believes that these languages are "the modern successors of Middle Indo-Aryan (MIA), Gandhari and other unknown MIA languages" (Zoller 2005, p. 10). He upholds that the Dardic languages developed from "Proto-Dardic" that branched off "at a post OIA stage from the rest of the Indic" (ibidem).

Bailey (1924, pp. xiii-xiv) classified Shina into three main dialectal groups. These are: (1) Gilgiti; (2) Astori (Astori, Gurezi and Drasi); (3) Kohistani (Kohistani and Chilasi).

Bailey considers Gilgit as the real home of the Shina language and reports that Shina country includes Gurez and Tiliel valleys of upper Kishenganga, Burzil valley, and the districts of Astor, Gilgit, Chilas and Kohistan. He further notes that the people of Gurez and Tiliel are bilingual and speak Kashmiri as well (ibidem). However, the field surveys, undertaken for the present study, revealed that only some of the inhabitants of Gurez are bilingual, while the rest of the people speak only Shina. Many people in Gurez proper do understand Kashmiri but their fluency in the language is limited. People of Tiliel are monolingual and speak only Shina. The author of the present 
study has tried to communicate with people of the area in Kashmiri, but it turned out that these people do not understand Kashmiri at all.

Strand (2001) bases his classification of Shina around two main groups: Chilasi and Gilgiti. According to him, "the dialect around Chilas in the east-west portion of the Indus valley above Indus Kohistan is probably the source of the speech that spread upstream along the Indus basin to form the Eastern Shina dialects and downstream to form the kohistyo dialect of Indus Kohistan. Another dialect centers on Gilgit, with an outlying Tibetanised offshoot (Brokshat) in Ladakh".

Bashir (2003, pp. 824-825) has proposed a detailed classification of the Dardic languages. According to her, the major groups have been arranged from West to East as follows: (I) Pashai; (II) Kunar; (III) Chitral; (IV) Kohistani; (V) Shina; (VI) Kashmiri.

As far as the Shina group is concerned, she divides it into four subgroups that include: (a) Kohistan (Kohistyo) [dialects of Palas, Jalkot, Koli], Ushojo, TangirDarel, Chilasi; (b) Astor (Astori, Drasi, Gurezi, Gultari); (c) Gilgit (Gilgiti, HunzaNagari, Punyali, Brokskat [Dokskat, Kyango]); (d) Palula [Dangarik (war)], Phalura, Paloladi (Sawi, Sauji).

According to her, the present-day Dardic languages were spoken in a much wider area than they are currently used and differential changes have occurred in the six language groups.

\section{The Area}

The valley of Gurez lies at the extreme north of Indian Kashmir in the Bandipora District $^{2}$. On its northern side the valley is demarcated from the areas falling under the control of Pakistan through concertinaed wires signifying the Line of Control (LOC). The river Kishenganga with its principal stream originating from the high altitude Gangbal lake, nestled in the Harmukh mountains, flows in east-west direction and runs through the middle of the valley. The river known by the name of Neelum in Pakistan serves as LOC towards the lower areas of Gurez. The valley is around 95 kilometres long and at a few places half a kilometre wide at the most. The rest of it is very narrow with sloping mountains on either side of the river giving it a characteristic V-shaped appearance. The villages are inhabited over flat pieces of land on either side of the river. The place becomes very scenic in summers, owing to the sparkling water of Kishenganga, the high mountains that are partly naked and partly green and the optimal temperature that ranges from twenty to thirty degrees centigrade. The valley has around forty-five small and big villages which are connected by a motor road run-

2 The northern state of Jammu and Kashmir in India comprises three administrative divisions: Southern Jammu, Northern Kashmir and Eastern Ladakh. The Jammu Division consists of eleven districts, the Ladakh Division has two districts (Leh and Kargil), and finally, the Kashmir Division has also eleven districts. These are as follows: Anantnag, Bandipora, Baramulla, Budgam, Ganderbal, Bandipora, Kulgam, Kupwara, Pulwama, Srinagar and Shopian. 
ning along the river bank. From the last village of Tiliel, the onward road towards the Dras area of Kargil District of Ladakh Division of Jammu and Kashmir has been blocked by the Indian Army for public traffic.

Gurez is connected to the district headquarters of Bandipora through a treacherous road that passes over the 11,672 feet high Razdaan pass and enters the valley through its southwestern side. The total distance from Bandipora to Gurez is 80 kilometres and it takes around five hours to reach there by a light motor vehicle. The road remains open for around six months from April to September or October. For the rest of the year it remains closed due to heavy snowfall. On average, the valley receives around twelve to fifteen feet of snow in winters. Occasionally, the government arranges helicopter services for the people including government officials for moving out or into the valley during winters. Because the area falls along the LOC, Gurez is highly militarised.

Gurez has the status of a tehsil ${ }^{3}$ and for administrative purposes the department of education has divided it into three sectors, the western sector of Bakhtor, the central Dawar and the eastern Tiliel. The road coming from district headquarters of Bandipora meets Bakhtor first, and then it passes through Dawar towards the eastern part of Tiliel. Dawar is the administrative centre of the valley.

\section{The Present Study}

The present study reports a part of the findings of a major research project entitled 'Description, Documentation and Preservation of Shina', sponsored by the University Grants Commission of India. The study is exclusively based on the data collected from the native speakers of Shina in Gurez valley. The database collected for the study is the outcome of seven field trips made to the valley between June 2011 and September 2012. The duration of each field trip was several days. The study engaged around thirty-three native speakers for consultation. The language consultants were carefully selected from villages falling in all the three sectors, the lower sector of Bakhtor, the central sector of Dawar and the upper sector of Tiliel.

The data have been primarily transcribed using SILDoulos IPA 93 font. To transcribe some of the retracted sounds, Unicode symbols have also been used.

Since no detailed study devoted to the variety of Shina spoken in Gurez has previously been undertaken, the present paper is the first attempt to describe this language. Previously, in 1899, Sir James Wilson provided a brief account of Gurezi Shina. The work identified a series of vowels and elucidated some of the elements of grammar. Grierson (1919) dedicated Part II of Volume VIII to Dardic languages which include Shina. His account of Shina is focused on the Gilgiti variety and in providing a short introduction of Gurezi Shina, Grierson relied on Wilson's work. Bailey's 'Grammar of the Shina Language' (1924) made short explanations on the phonology and other grammatical aspects of Kohistani, Gurezi and Drasi varieties, but the primary

\footnotetext{
${ }^{3}$ A tehsil is a sub-administrative unit of a district.
} 
concern of the work was Shina spoken in Gilgit. The only detailed study on the phonology of a variety of Shina spoken in Indian Kashmir was written by B. B. Rajapurohit in 1983, under the patronage of the Central Institute of Indian Languages (CIIL), Mysore. The work developed and reported the phonological system of the Drasi variety of Shina. Since the language lacks a writing script, the author proposed a script for Shina, using Perso-Arabic as well as Devnagri alphabets. The first study dedicated exclusively to Gurezi Shina is that of Schmidt and Kaul (2010), in which the authors presented a brief grammatical sketch of the language which also comprises a short description of phonology. Though the sounds of the language are mentioned, no examples are given from Gurezi Shina, either in the form of minimal pairs or the distribution of the sounds. However, with regard to nouns and verbs of Gurezi, due examples are enumerated.

Several studies on the varieties of Shina spoken in Pakistan have been pursued at the Institute of Pakistan Studies, Quad-i-Azam University, Islamabad, Pakistan and varieties like Gilgiti and Kohistani Shina have been well documented. Among these, the works of Radloff (1999), and Schmidt and Kohistani (2008) are significant. Radloff's Aspects of the Sound System of Gilgiti Shina is a comprehensive study of the sounds of Gilgiti Shina, including a concise account of the pitch-accent of the language. A Grammar of the Shina Language of Indus Kohistan by Schmidt and Kohistani presents an extensive far-flung description of the grammatical aspects of Kohistani Shina. Both works are supported by data collected in fieldwork.

In the explanation of vowels, the present study has made use of labels like close-open and front-back, and in the description of consonants, conventional terms like manner of articulation, place of articulation, voiced-voiceless have been used. The vowel and consonant sounds have been explained by examples in the form of minimal pair of words as well as their distribution in words.

\section{Vowels}

The vowel system of Gurezi Shina is based on five basic vowels with length and nasalisation being distinctive. All the five short oral vowels have a longer counterpart and all the resulting ten vowels have nasalised counterparts. This puts the number of vowels in Gurezi at twenty. The database shows some very short vowels; however, these have been categorised as short vowels, since these were not found in sufficient contexts for the formation of minimal pairs. Schmidt and Kaul (2010, p. 196) put the number of basic vowels in Gurezi ${ }^{4}$ at six. According to the authors, there is an extra vowel / $\mathrm{J} /$ in Tilieli which is absent in Gurezi. No such vowel could be found in the database collected for the present study. Radloff (1999, pp. 16-19) reported the presence of five basic vowels in Gilgiti Shina with length and nasalisation being distinctive, making the number of vowels in Gilgiti at twenty. Schmidt and Kohistani (2008,

${ }^{4}$ Schmidt and Kaul (2010) treat Gurezi and Tilieli as separate dialects, which according to the opinion of the author is a debatable issue. 
pp. 15-18) report the presence of an extra low front vowel besides the above, which the authors believe is present in the loanwords in Kohistani Shina. According to Rajapurohit (1983, pp. 15-20), Drasi Shina has only fourteen vowels with nasalisation being non-distinctive. He also posits the presence of seven diphthongs in Drasi. An overview of the vowel phonemes found in the database collected for Gurezi Shina is presented below:

Short and long oral vowels

\begin{tabular}{|c|c|c|c|}
\hline & Front & Central & Back \\
\hline Close & $\mathrm{i}$ & & $\mathrm{u}$ \\
\hline Mid & $\mathrm{e}$ & & o \\
\hline Open & & $\mathrm{a}$ & \\
\hline
\end{tabular}

\section{Short and long nasalised vowels}

\begin{tabular}{|c|c|c|c|c|}
\hline & & & Central & \\
\hline Close & $\tilde{1}$ & $\tilde{11}$ & & $\tilde{u}$ \\
\hline Mid & $\tilde{\mathrm{e}}$ & ẽẽ & & $\tilde{0}$ \\
\hline Open & & & $\tilde{a}$ & \\
\hline
\end{tabular}

\subsection{Vowel Phoneme-contrast}

The use of minimal pair of words is a recognised technique in the description of the contrastive (phonemic) sounds of a language. Two different words of identical phonological structure except for a difference of single sound are referred to as minimal pair of words. For example, English /pin/ versus /bin/. However, the distinction in a minimal pair can be based on vowel length or vowel nasalisation or some other distinctive phonological feature. For example, vowel length in Gurezi Shina is distinctive, so short /a/ and long/aa/ are separate phonemes and so are oral /a/ and nasalised /ã/ in minimal pairs /bas/ 'stop' and /baas/ 'night', and /bai/ 'twelve' and /bãi/ 'cattle shed', respectively. There is a distinctive use of pitch-accent in Gurezi Shina, so the difference in a minimal pair of words can be based on the placement of pitch-accent, as in /akáai/ and /akaái/; the former meaning 'eleven' and the latter 'fast'.

\subsection{Short versus Long Vowels}

\begin{tabular}{|c|c|c|c|c|}
\hline$/ \mathbf{a} /$ vs. /aa/ & $\begin{array}{l}/ \int \mathrm{al} / \\
/ \mathrm{bai} / \\
/ \mathrm{k}^{\mathrm{h}} \mathrm{as} / \\
/ \mathrm{gt}_{\mathrm{h}}^{\mathrm{h}} / \\
/ \text { was/ } \\
\text { /sas/ }\end{array}$ & $\begin{array}{l}\text { hundred } \\
\text { cooked rice } \\
\text { to sweep } \\
\text { fearing } \\
\text { come down } \\
\text { sister }\end{array}$ & $\begin{array}{l}\text { / Jaal/ } \\
\text { /baai/ } \\
/ \int \mathrm{k}^{\mathrm{h}} \text { aas/ } \\
/ \int \mathrm{t}^{\mathrm{h}} \text { aal/ } \\
\text { /waas/ } \\
\text { /saas/ }\end{array}$ & $\begin{array}{l}\text { shivering } \\
\text { twelve } \\
\text { to polish } \\
\text { goat's kid } \\
\text { open surface } \\
\text { thousand }\end{array}$ \\
\hline
\end{tabular}




\begin{tabular}{|c|c|c|c|c|}
\hline /e/ vs. /ee/ & /e/ & come (request) & /ee/ & after coming \\
\hline & /ke/ & why & /kee/ & crows \\
\hline & /se/ & fix (imp.) & /see/ & engaged \\
\hline /i/ vs. /ii// & $/ \mathrm{si} /$ & to sew & /sii/ & fine girl \\
\hline & $\begin{array}{l}/ \mathrm{li} / \\
/ \mathrm{mi} /\end{array}$ & $\begin{array}{l}\text { to uproot } \\
\text { urinate }\end{array}$ & $\begin{array}{l}/ \mathrm{lii} / \\
/ \mathrm{mii} /\end{array}$ & $\begin{array}{l}\text { call a girl } \\
\text { fat }\end{array}$ \\
\hline /o/vs. /oo/ & /so/ & that & /soo/ & illegitimate male child \\
\hline & /zo/ & he/that & /Şoo/ & nephew \\
\hline & $/ \mathrm{mos} /$ & I & /moos/ & meat \\
\hline /u/ vs. /uu/ & $\begin{array}{l}\text { /kutu/ } \\
\text { /mutu/ }\end{array}$ & $\begin{array}{l}\text { knee } \\
\text { next }\end{array}$ & $\begin{array}{l}\text { /kuutu/ } \\
\text { /muutu/ }\end{array}$ & $\begin{array}{l}\text { deaf } \\
\text { death }\end{array}$ \\
\hline
\end{tabular}

\subsection{Oral versus Nasalised Vowels}

\begin{tabular}{|c|c|c|c|c|}
\hline /a/ vs. /ãa/ & /rai/ & plant disease & /rãi/ & canal turn \\
\hline & /trai/ & window & /trãi/ & sound of slap \\
\hline /aa/ vs. /ãã/ & /maai/ & mother & /mããi/ & laziness \\
\hline & /kaari/ & for & /kããri/ & coal \\
\hline & /baai/ & twelve & /bããi/ & shuttle (weaver) \\
\hline /e/ vs. /ẽ/ & /bej/ & sit & /bẽj/ & willow tree \\
\hline /i/ vs. /î/ & / $\mathrm{ai} /$ & hope & $/$ /ãĩ/ & colliding sound \\
\hline /ii/ vs. / /ĩ/ & /dii/ & daughter & /dĩĩ/ & leopard \\
\hline & /mii/ & fat & /mĩi / & will urinate \\
\hline /o/ vs. / $\tilde{\mathbf{o}} /$ & $/ \mathrm{mos} /$ & I & /mõs/ & meat/mutton \\
\hline oo/ vs. / $\tilde{\mathbf{o}} \tilde{\mathbf{o}} /$ & /sooi/ & while sleeping & /sõõi/ & that (verily) \\
\hline & /mutu/ & next & /mũtu/ & brain \\
\hline 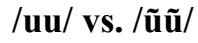 & 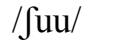 & ladder & $/ \int \tilde{u} \tilde{u} /$ & $\operatorname{dog}$ \\
\hline
\end{tabular}

Radloff (1999, p. 19) has not been able to find an example of short nasalised /ẽ/ in Gilgiti Shina, however, the database for the present study has one such example with the short nasalised midfront short vowel; /bẽj/ meaning 'willow'.

\section{Consonant Phonemes}

Radloff (1999, p. 121) proposed thirty-four consonant phonemes for Gilgiti Shina. She classified the consonants of Gilgiti Shina on the basis of manner and place of articulation and voiceless and voiced distinction. Schmidt and Kohistani (2008, pp. 16-23) mentioned some phonemes for Kohistani Shina, in addition to the thirty-four ones above. These additional sounds are mostly the aspirated ones, including $/ \mathrm{b}^{\mathrm{h}} /, / \mathrm{d}^{\mathrm{h}} /$, $/ \mathrm{d}^{\mathrm{h}} /, / \mathrm{g}^{\mathrm{h}} /, / \mathrm{m}^{\mathrm{h}} /, / 1^{\mathrm{h}} /$. Besides, these authors also reported the presence of both voiced and voiceless velar fricatives $/ \mathrm{x} /$ and $/ \chi /$ and post-velar plosive $/ \mathrm{q} /$ in Kohistani Shina. Rajapurohit (1983, p. 21) reported thirty-six consonant phonemes for Drasi Shina. The 
author mentions the presence of velar fricatives $/ \mathrm{x} /$ and $/ \chi /$ in Drasi, but does not mention the voiceless retroflex fricative $/ \mathrm{s} /$ and the labial glide $/ \mathrm{w} /$. Besides, the author also reports the presence of alveo-palatal fricative /ž/ in Drasi. For Gurezi Shina, Schmidt and Kaul (2010, p. 197) proposed thirty-four consonants for Gurezi and for Tilieli, and they posited two additional consonants, including the labio-dental fricative /f/ and the voiced retracted affricate $/ 3 /$.

For the elaboration of the consonant phonemes, the traditional labels of place of articulation and manner of articulation and the distinction of voice have been used here.

The analysis of the data collected for the present study reveal the presence of thirty-four consonant phonemes in Gurezi Shina. These include twelve plosives, seven affricates, six fricatives, four nasals, two glides, one lateral and two flaps. The unique feature of Gurezi phonology is the presence of many retroflex sounds. As many as nine retroflex sounds are present in Gurezi. This is quite in tune with the observation of Radloff (1999, pp. 23-31).

The retroflex sounds include the following: / $t t^{h} d t \quad t \quad t^{h} s \quad z \quad n \quad r /$.

As far as their distribution in the words is concerned, all the above retroflex sounds can be found as word-initials, medials and finals, except for the sound $/ \mathrm{r} /$ for which no example was found in initial position.

\subsection{Plosives and Flaps}

Plosives are sounds in which there is a momentary but complete stoppage of the air coming out of lungs which when released causes an audible explosion sound. Flaps are also plosives in that sense, but the time period during which the closure is made is of very small duration in flaps in contrast to plosives. In effect the only difference between a flap and a plosive is that the former is a plosive of very small time duration and as such they have been treated together.

\subsubsection{Voiceless versus Voiced}

$\begin{array}{lllll}\text { Phonemic contrast } & \text { Gurezi } & \text { Glossary } & \text { Gurezi } & \text { Glossary } \\ \text { /p/ vs. /b/ } & \text { /puur/ } & \text { storey } & \text { /buur/ } & \text { sunset } \\ & \text { /puuri/ } & \text { complete } & \text { /buuri/ } & \text { peak }\end{array}$

\section{Consonant phonemes of Gurezi Shina}

\section{Labial Dental Retroflex Palatal Velar Glottal}

Plosive

Aspirated

Voiceless

Voiced

Retr

Affricate

Aspirated

\section{Alveolar}

$t^{h}$

$$
\begin{aligned}
& \mathrm{k}^{\mathrm{h}} \\
& \mathrm{k} \\
& \mathrm{g}
\end{aligned}
$$


Voiceless

Voiced

Fricative

Voiceless

Voiced

Nasal

$\mathrm{m}$

Glide

Lateral

Flap ts

Phonemic contrast /p/ vs. /b/

/t/ vs. /d/

/t/ vs. /d/

$/ \mathbf{t} /$ vs. $/ \mathbf{r} /$

/k/vs. /g/
S

Z

n

W

1 t

S $\quad$ J

Z

$\eta$

r $\mathrm{h}$

$\mathfrak{j}$

\section{Gurezi Glossary}

/bonf/ $\quad \log$

/boi/ sleeve

/ban/ joint

/bon/ to wear

/baku/ tree branch

/bar/ breadth

/baas/ stream

/baas/ night

/doomu/ thread

/dap/ to be silent

/dar/ door

/doni/ leg

/dim/ body

/badi/ big

/mudu/ timid

/maru/ lifeless/dead body

$\begin{array}{llll}\text { /kee/ crows } & \text { /gee/ } & \text { having gone } \\ \text { /bakeeru/ } & \text { slaughtering animal /bageeru/ } & \text { husky voiced }\end{array}$

$/ \mathrm{katu} / \quad$ without tail $/ \mathrm{gatu} /$ translucent

/kon/ ear

/gon/

knot

\subsubsection{Voiceless versus Voiceless Aspirated}

\begin{tabular}{|c|c|c|c|c|}
\hline $\begin{array}{l}\text { Phonemic contrast } \\
/ \mathbf{p} / \mathbf{v s} . / \mathbf{p}^{\mathrm{h}} /\end{array}$ & $\begin{array}{l}\text { Gurezi } \\
\text { /pas/ } \\
\text { /pusu/ } \\
\text { /puuri/ } \\
\text { /poot/ } \\
\text { /puunu/ } \\
\text { /paad/ } \\
\text { /poy/ }\end{array}$ & $\begin{array}{l}\text { Glossary } \\
\text { wool } \\
\text { flower } \\
\text { complete } \\
\text { embroidered } \\
\text { full } \\
\text { shoe sole } \\
\text { loosely bound }\end{array}$ & $\begin{array}{l}\text { Gurezi } \\
/ \mathrm{p}^{\mathrm{h}} \text { as / } \\
/ \mathrm{p}^{\mathrm{h} u s u /} \\
/ \mathrm{p}^{\mathrm{h}} \text { uuri/ } \\
/ \mathrm{p}^{\mathrm{h}} \text { oot/ } \\
/ \mathrm{p}^{\mathrm{h}} \text { uuyu/ } \\
/ \mathrm{p}^{\mathrm{h}} \text { aad/ } \\
/ \mathrm{p}^{\mathrm{h}} \text { oy/ }\end{array}$ & $\begin{array}{l}\text { Glossary } \\
\text { finish } \\
\text { empty } \\
\text { light snow } \\
\text { to bring land } \\
\text { under cultivation } \\
\text { maize stakes } \\
\text { log } \\
\text { to nod shoulders } \\
\text { in temper }\end{array}$ \\
\hline
\end{tabular}




\begin{tabular}{|c|c|c|c|c|}
\hline$/ \mathbf{t} / \mathbf{v s} . / \mathbf{t}^{\mathrm{h}} /$ & $/ \operatorname{tar} /$ & bud & $/ \mathrm{t}^{\mathrm{h}} \mathrm{ar} /$ & startled \\
\hline & /tap/ & bent/fold & $/ \mathrm{t}^{\mathrm{h}} \mathrm{ap} /$ & darkness \\
\hline$/ \mathbf{t} /$ vs. $/ \mathbf{t}^{\mathbf{h}} /$ & $/ \mathrm{tam} /$ & falling & $/ \mathrm{t}^{\mathrm{h}} \mathrm{am} /$ & sweeping \\
\hline & $/ \operatorname{tar} /$ & $\log / \operatorname{lie}$ & $/ t^{\mathrm{h}} \mathrm{ar} /$ & peeling/weathering \\
\hline$/ \mathbf{k} /$ vs. $/ \mathbf{k}^{\mathrm{h}} /$ & $\begin{array}{l}\text { /taak/ } \\
\text { /koor/ }\end{array}$ & $\begin{array}{l}\text { to fix temporarily } \\
\text { rock }\end{array}$ & $\begin{array}{l}/ \mathrm{t}^{\mathrm{t}} \text { aak/ } \\
/ \mathrm{k}^{\mathrm{h}} \text { oor/ }\end{array}$ & $\begin{array}{l}\text { prohibit } \\
\text { horse shoe }\end{array}$ \\
\hline & /kuru/ & hard & $/ \mathrm{k}^{\mathrm{h}} \mathrm{uru} /$ & lame \\
\hline & /kom/ & a flower & $/ \mathrm{k}^{\mathrm{h}} \mathrm{om} /$ & to eat \\
\hline & /koi/ & peas & $/ \mathrm{k}^{\mathrm{h}} \mathrm{oi} /$ & cap \\
\hline & /kon/ & ear & /k on/ & mountain pass \\
\hline & /kutu/ & knee & $/ \mathrm{k}^{\mathrm{h}} \mathrm{u} \mathrm{tu} /$ & short \\
\hline & /keen/ & big stone & $/ \mathrm{k}^{\mathrm{h}}$ een/ & time \\
\hline
\end{tabular}

\subsubsection{Dental versus Retroflex}

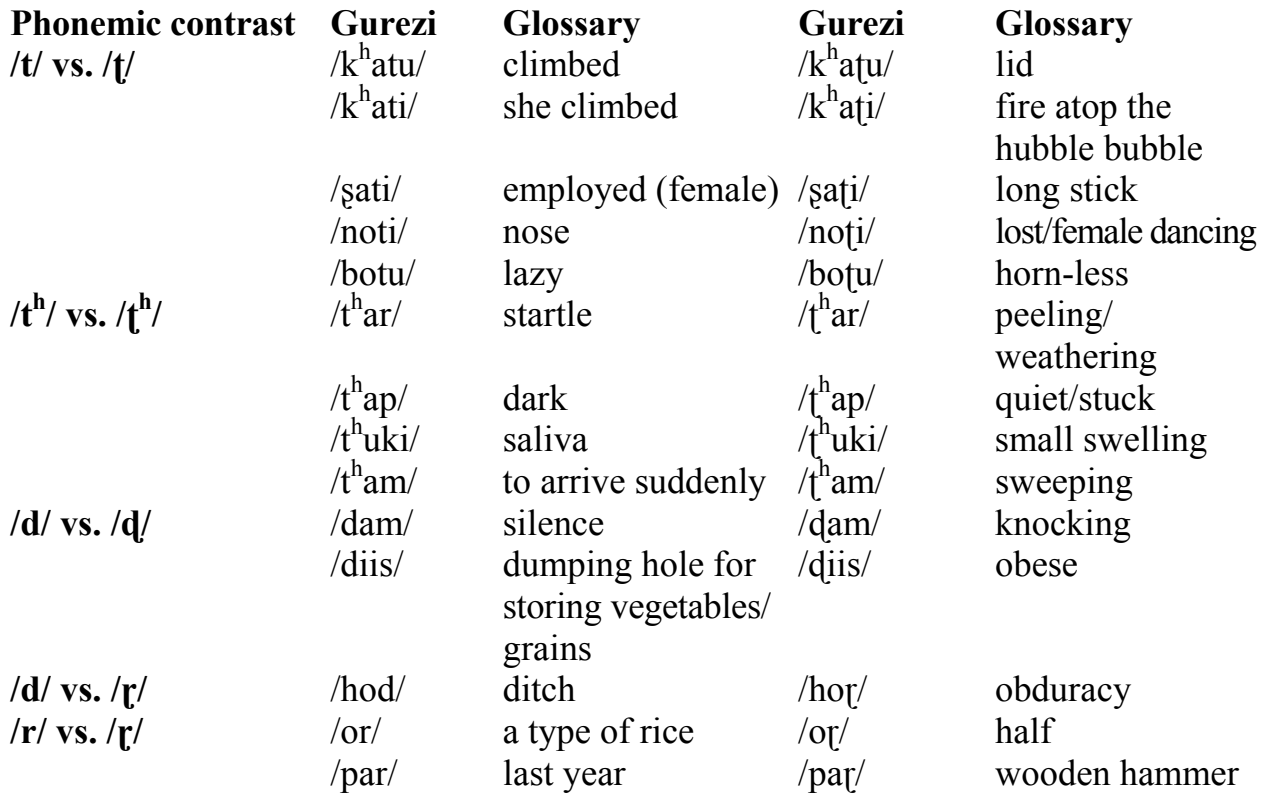

\subsubsection{Plosives /d/versus Flap $/ \gamma^{\prime}$}

In the following some more examples of the above two phonemes are presented. The examples show the contrast between the phonemes in analogous environment.

$\begin{array}{lllll}\text { Phonemic contrast } & \text { Gurezi } & \text { Glossary } & \text { Gurezi } & \text { Glossary } \\ \text { /d/ vs. /r/ } & \text { /mudu/ } & \text { silly } & / \text { maru/ } & \text { dead body } \\ & \text { /dap/ } & \text { quiet } & / \text { doori/ } & \text { handle } \\ & \text { /dil/ } & \text { roll down } & / \mathrm{par} / & \text { wooden hammer } \\ & / \mathrm{keend} / & \text { big stone } & / \mathrm{kon} / & \text { ear } \\ & / \mathrm{k}^{\mathrm{h}} \text { eend/ } & \text { time } & / \mathrm{k}^{\mathrm{h}} \text { oon/ } & \text { hill }\end{array}$




\subsubsection{Distribution of Plosives and Flaps}

The examples below present the distribution of the Gurezi Shina plosive and flap consonant phonemes in three basic positions in a word, i.e. in initial, intervocalic and final position.

\begin{tabular}{|c|c|c|c|c|c|c|}
\hline & Initial & Glossary & Intervocalic & Glossary & Final & Glossary \\
\hline$/ \mathbf{p} /$ & /putf/ & son & /tfape/ & chew & /zaap/ & unconscious \\
\hline & /pranu/ & moth & /t fapaat $\int /$ & slap & /roopu/ & silver \\
\hline$/ \mathbf{p}^{\mathbf{h}} /$ & $\begin{array}{l}/ \mathrm{p}^{\mathrm{h}} \mathrm{unu} / \\
/ \mathrm{p} \text { uuri/ }\end{array}$ & $\begin{array}{l}\text { sliced maize } \\
\text { light snow }\end{array}$ & $\begin{array}{l}\text { /t } \int^{\mathrm{h}} \text { ap } \mathrm{h} \text { at/ } \\
/ \text { nap } \mathrm{hr} /\end{array}$ & $\begin{array}{l}\text { dead } \\
\text { eve swelling }\end{array}$ & $\begin{array}{l}/ \mathrm{t}^{\mathrm{h}} \mathrm{ap} / \\
/ \mathrm{dap}^{\mathrm{h}} /\end{array}$ & $\begin{array}{l}\text { darkness } \\
\text { quiet }\end{array}$ \\
\hline & /phutuusu/ & half burnt & /aphuri/ & $\begin{array}{l}\text { loosely } \\
\text { bound }\end{array}$ & /laaph/ & pride \\
\hline$/ \mathbf{b} /$ & /baal/ & boy & /grabaal/ & $\begin{array}{l}\text { excreta of } \\
\text { new born } \\
\text { cattle }\end{array}$ & /daab/ & attic \\
\hline$/ \mathbf{t} /$ & /tuken/ & by you & /patanoo/ & later on & /dut/ & milk \\
\hline & /tom/ & tree & /satu/ & raised land & /hiit/ & excuse \\
\hline & /tun/ & navel & /matu/ & hermit & /jaat/ & gait \\
\hline$/ t^{\mathrm{h}} /$ & $/ \mathrm{t}^{\mathrm{h}} \mathrm{ap} /$ & darkness & /bat ${ }^{\mathrm{h}}$ aaru/ & bedding & /hat ${ }^{\mathrm{h}} /$ & hand \\
\hline & $\begin{array}{l}\text { /t uk1/ } \\
\text { /thuri// }\end{array}$ & $\begin{array}{l}\text { saliva } \\
\text { heel }\end{array}$ & $\begin{array}{l}\text { /sat razi/ } \\
\text { /sut er/ }\end{array}$ & line & & \\
\hline$/ \mathbf{t} /$ & /tukuri/ & basket & /atoonu/ & to bring & lat/ & sudden \\
\hline & $\begin{array}{l}\text { /tupi/ } \\
\text { /tookar/ }\end{array}$ & $\begin{array}{l}\text { cap } \\
\text { grasshopper }\end{array}$ & $\begin{array}{l}\text { /photooni/ } \\
\text { /bitakatu/ }\end{array}$ & $\begin{array}{l}\text { a wild seed } \\
\text { blurred }\end{array}$ & $\begin{array}{l}\text { /sat/ } \\
\text { /mot/ }\end{array}$ & $\begin{array}{l}\text { to beat } \\
\mathrm{me} / \mathrm{I}\end{array}$ \\
\hline & & & & vision & & \\
\hline$/ \mathbf{t}^{\mathbf{h}} /$ & $/ \mathrm{t}^{\mathrm{h}} \mathrm{am} /$ & sweep & $/ \mathrm{pat}^{\mathrm{h}} \mathrm{an} /$ & brave & $/ \int \bar{o} \bar{o} t^{h} /$ & a wild fruit \\
\hline$/ \mathbf{d} /$ & /dom/ & slope & /badu/ & big/elder & /brand/ & fall down \\
\hline$/ \mathbf{d} /$ & /daadu/ & grandfather & /sadu/ & saint & $/ \mathrm{raad} /$ & stump \\
\hline & /doonu/ & ox & /badwaa/ & bad habit & & \\
\hline$/ \mathbf{k} /$ & /kuutu/ & deaf & /tukuri/ & basket & /3uk/ & whole \\
\hline & /kon/ & ears & /phukar/ & snow storm & $/ p^{h} u k /$ & a piece \\
\hline$/ \mathbf{k}^{\mathbf{h}} /$ & $/ \mathrm{k}^{\mathrm{h}} \mathrm{u} \mathrm{u} \mathrm{u} /$ & left handed & /ph $\mathrm{uk}^{\mathrm{h}}$ een/ & $\begin{array}{l}\text { evening } \\
\text { tea time }\end{array}$ & /muk ${ }^{\mathrm{h}} /$ & face \\
\hline & $/ \mathrm{k}^{\mathrm{h}_{\text {iniiru/ }}}$ & bent/twisted & /sak ${ }^{\mathrm{h}} \mathrm{rei} /$ & to stop & $/ \mathrm{akk}^{\mathrm{h}} /$ & quickly \\
\hline$/ g /$ & /gaaw/ & cow & /mugur/ & bowl & /dag/ & pain \\
\hline & /gon/ & knot & /bageru/ & husky voiced & /draag/ & famine \\
\hline$/ \mathbf{r} /$ & /ran/ & lamb & /tran/ & fire & /sar/ & pond \\
\hline & & queen & /paraar/ & $\begin{array}{l}\text { year before } \\
\text { last year }\end{array}$ & zar & slip \\
\hline$/ \mathbf{r} /$ & $/ \mathrm{maru} /$ & $\begin{array}{l}\text { lifeless/deac } \\
\text { body }\end{array}$ & /gor/ & ankle & & \\
\hline
\end{tabular}




\subsection{Affricates and Fricatives}

Gurezi Shina has the following affricate and fricative consonant phonemes:

/ ts, $\mathrm{ts}^{\mathrm{h}} \mathrm{t} \int \mathrm{t}^{\mathrm{h}}, 3, \mathrm{~s}, \mathrm{z}, \mathrm{z}_{\mathrm{L}} /$

In the following the affricates and fricatives of Gurezi Shina are presented contrasted for voice, aspiration and retraction. Retraction is an important feature of sounds in Gurezi Shina and as such there are a number of retroflex fricatives and affricates.

\subsubsection{Voiceless versus Voiced}

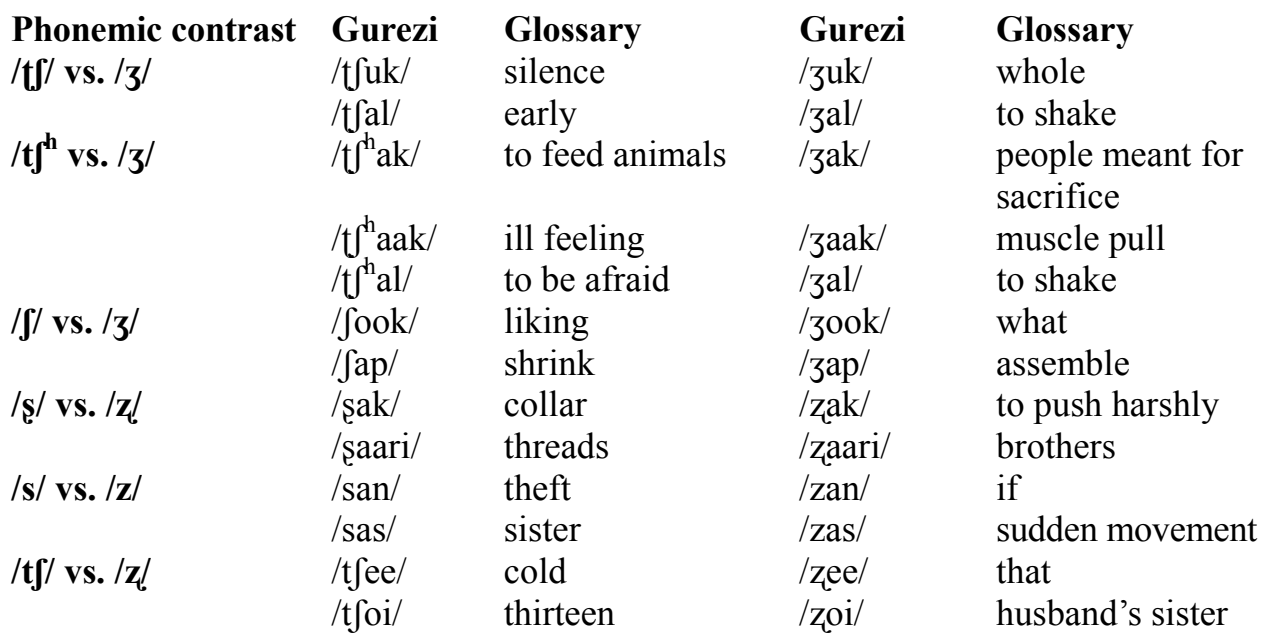

\subsubsection{Voiceless versus Voiceless Aspirated}

\begin{tabular}{|c|c|c|c|c|}
\hline $\begin{array}{l}\text { Phonemic contrast } \\
/ \text { ts/ vs. } / \text { ts }^{\mathrm{h}} /\end{array}$ & $\begin{array}{l}\text { Gurezi } \\
\text { /tsik/ } \\
\text { /tsep/ }\end{array}$ & $\begin{array}{l}\text { Glossary } \\
\text { play } \\
\text { to take respon- }\end{array}$ & $\begin{array}{l}\text { Gurezi } \\
/ \mathrm{ts}^{\mathrm{h}} \mathrm{ik} / \\
/ \mathrm{s}^{\mathrm{h}} \mathrm{ep} /\end{array}$ & $\begin{array}{l}\text { Glossary } \\
\text { lighten } \\
\text { hiding }\end{array}$ \\
\hline$/ \mathbf{s} /$ vs. $/ \mathbf{t s}{ }^{\mathrm{h}} /$ & /sar/ & pond & $/ \mathrm{ts}^{\mathrm{h}} \mathrm{ar} /$ & milking \\
\hline$/ \mathbf{t} \int /$ vs. $/ \mathbf{t} \mathbf{f}^{\mathrm{h}} /$ & $\begin{array}{l}\text { /say/ } \\
/ \text { t5om/ }\end{array}$ & & $\begin{array}{l}\text { ts } \mathrm{s} \text { an/ } \\
/ \mathrm{t} \mathrm{S}^{\mathrm{h}} \mathrm{om} /\end{array}$ & $\begin{array}{l}\text { to k11l and eat } \\
\text { dust }\end{array}$ \\
\hline $\begin{array}{l}/ \mathbf{s} / \text { vs. } / \mathbf{t} \int^{\mathbf{h}} / \\
/ \mathbf{f} / \text { vs. } /\left.\mathbf{t}\right|^{\mathrm{h}} /\end{array}$ & $\begin{array}{l}\text { /t } \text { fok/ } \\
\text { /pas/ } \\
\text { / } \mathrm{ar} /\end{array}$ & $\begin{array}{l}\text { kitchen stand } \\
\text { wool } \\
\text { tear }\end{array}$ & $\begin{array}{l}/ \mathrm{t}^{\mathrm{h}} \mathrm{ok} / \\
/ \mathrm{pat} \int^{\mathrm{h}} / \\
/\left.\mathrm{t}\right|^{\mathrm{h}} \mathrm{ar} /\end{array}$ & $\begin{array}{l}\text { churning } \\
\text { season } \\
\text { sense }\end{array}$ \\
\hline
\end{tabular}

6.2.3. Retroflex versus Non-retroflex

\begin{tabular}{|c|c|c|c|}
\hline $\begin{array}{l}\text { Phonemic contrast } \\
/ \mathbf{t} / \text { vs. } / \mathrm{t} /\end{array}$ & $\begin{array}{l}\text { Gurezi } \\
\text { /katf/ } \\
\text { /utfe/ }\end{array}$ & $\begin{array}{l}\text { Glossary } \\
\text { arm pit } \\
\text { to pick }\end{array}$ & $\begin{array}{l}\text { Gurezi } \\
\text { /katS/ } \\
\text { /utfe/ }\end{array}$ \\
\hline
\end{tabular}




\begin{tabular}{|c|c|c|c|c|}
\hline$/ t \int^{h} /$ vs. $/ \mathrm{t} \int^{\mathrm{h}} /$ & /lat $\int^{\mathrm{h} /}$ & lakh & /lath/ & sheep \\
\hline & $/ \mathrm{t} \int^{\mathrm{h}} \mathrm{om} /$ & skin & $/ \mathrm{t} \int^{\mathrm{h}} \mathrm{om} /$ & pricking \\
\hline /s/ vs. / / / & /baas/ & night & /baa $/$ & lung \\
\hline & $/ \mathrm{k}^{\mathrm{h}} \mathrm{as} /$ & come upstairs & $/ \mathrm{k}^{\mathrm{h}} \mathrm{a} \mathrm{j} /$ & sweeping \\
\hline /z/ vs. /z/ & $\begin{array}{l}\text { /moozi/ } \\
\text { /zoi// }\end{array}$ & $\begin{array}{l}\text { months } \\
\text { yak }\end{array}$ & $\begin{array}{l}\text { /moozi/ } \\
\text { /zoi/ }\end{array}$ & $\begin{array}{l}\text { talks } \\
\text { husband's sister }\end{array}$ \\
\hline /z/ vs. /zl & $\begin{array}{l}\text { /zuk/ } \\
\text { /moozi/ }\end{array}$ & $\begin{array}{l}\text { whole } \\
\text { in between }\end{array}$ & $\begin{array}{l}\text { /zuk/ } \\
\text { /moozi// }\end{array}$ & $\begin{array}{l}\text { ill will } \\
\text { talks }\end{array}$ \\
\hline
\end{tabular}

\subsubsection{Other Affricates and Fricatives}

In the following we present the contrast for some other affricates and fricatives not included in the above list:

\begin{tabular}{|c|c|c|c|c|}
\hline Phonemic contrast & Gurezi & Glossary & Gurezi & Glossary \\
\hline$/ \mathbf{t s} /$ vs. $/ \mathbf{t} \mathbf{J} /$ & /tsap/ & touch & $/ \mathrm{t} \int \mathrm{ap} /$ & stealing \\
\hline$/$ ts/ vs. /s/ & /tsar/ & cutting/tearing & /sar/ & pond/lake \\
\hline$/ \mathbf{h} / \mathbf{v s .} / \mathbf{s} /$ & /har/ & take away & /sar/ & pond/lake \\
\hline$/ \mathbf{t} /$ vs. $/ \mathbf{f} /$ & /t $\int a a r /$ & straight & $/ \int \operatorname{ar} /$ & misfortune \\
\hline
\end{tabular}

\subsubsection{Distribution of Affricates and Fricatives}

The distribution of affricate and fricative consonant phonemes in word-initial, intervocalic and word-final positions are given below:

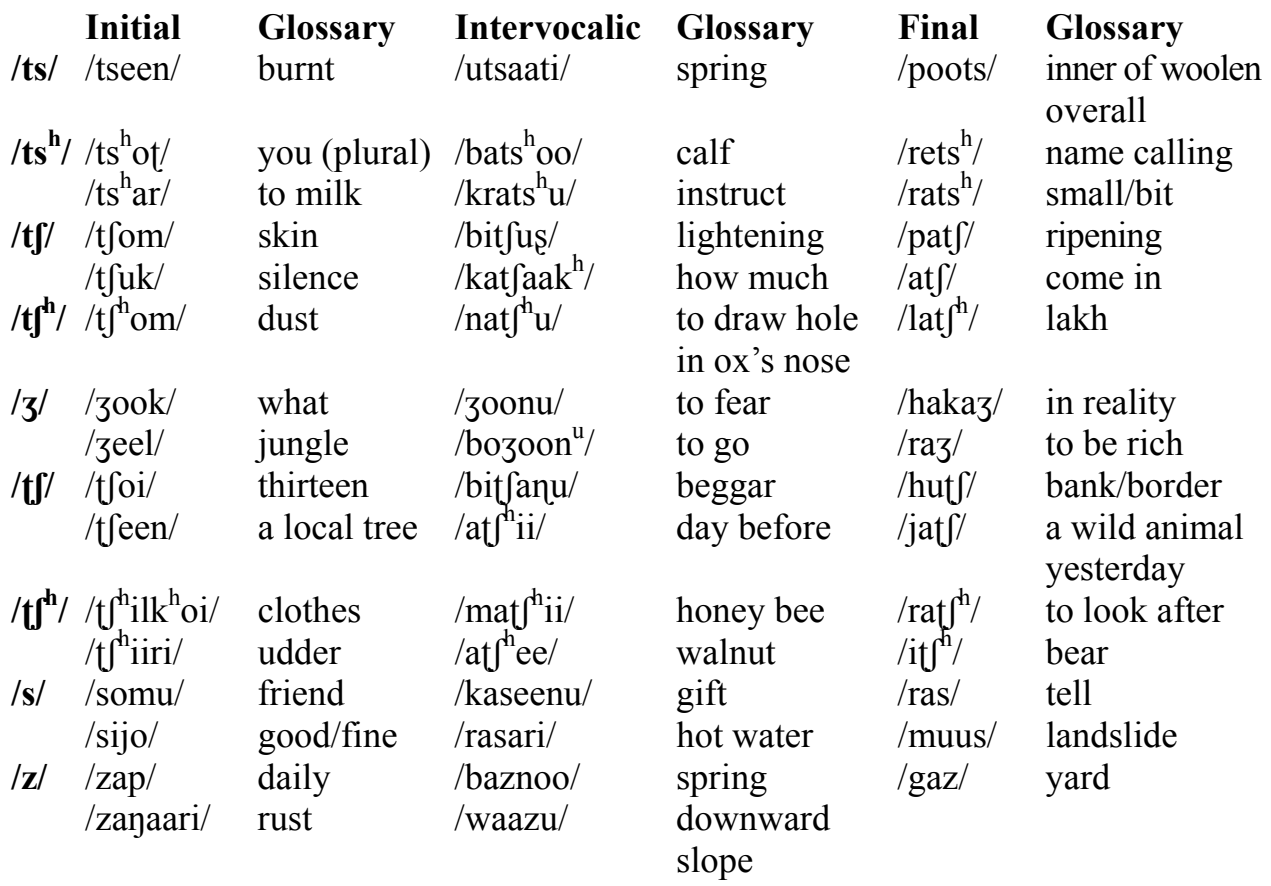




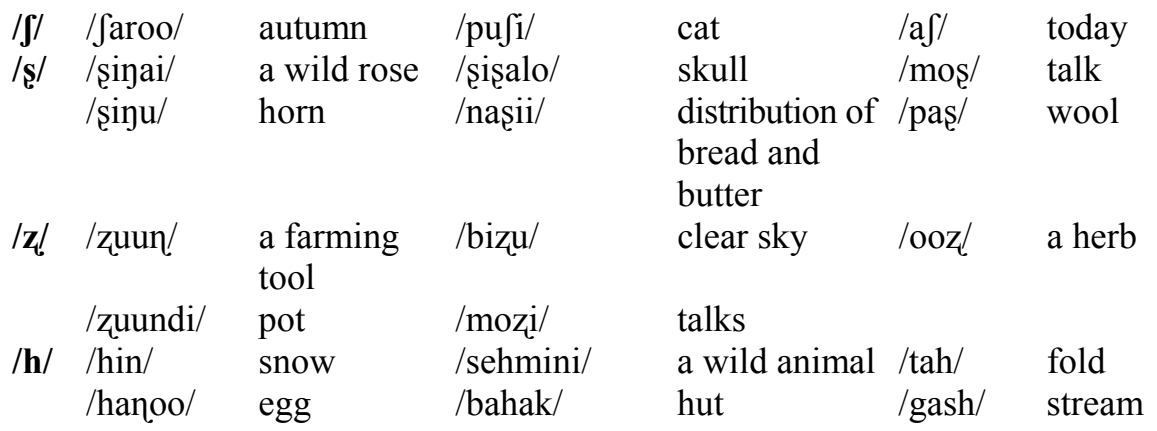

\subsection{Nasals, Laterals and Glides}

Gurezi Shina has the following nasal, lateral and glide consonants:

/ $\mathrm{m}, \mathrm{n}, \mathrm{n}, \mathrm{\eta}, \mathrm{l}, \mathrm{w}, \mathrm{j} /$

\subsubsection{Nasals}

\begin{tabular}{|c|c|c|c|c|}
\hline $\begin{array}{l}\text { Phonemic contrast } \\
\text { /m/ vs. /n/ } \\
/ \mathbf{m} / \text { vs. /n/ } \\
/ \mathbf{m} / \text { vs. } / \mathbf{n} / \\
/ \mathbf{n} / \mathrm{vs.} / \mathbf{n} / \\
/ \mathbf{n} / \mathrm{vs} . / \mathbf{n} /\end{array}$ & $\begin{array}{l}\text { Gurezi } \\
\text { /mor/ } \\
\text { /sam/ } \\
\text { /pon/ } \\
\text { /bran/ } \\
\text { /pon/ }\end{array}$ & $\begin{array}{l}\text { Glossary } \\
\text { peacock } \\
\text { right } \\
\text { way } \\
\text { to fall down } \\
\text { way }\end{array}$ & $\begin{array}{l}\text { Gurezi } \\
\text { /nor/ } \\
\text { /say/ } \\
\text { /pon/ } \\
\text { /bray/ } \\
\text { /pon/ }\end{array}$ & $\begin{array}{l}\text { Glossary } \\
\text { tiny part } \\
\text { light } \\
\text { leaves } \\
\text { lightened } \\
\text { loosely bound }\end{array}$ \\
\hline
\end{tabular}

In Gurezi Shina both velar nasals and retroflex nasals have separate phonemic identity as is clear from the above.

\subsubsection{Laterals and Glides}

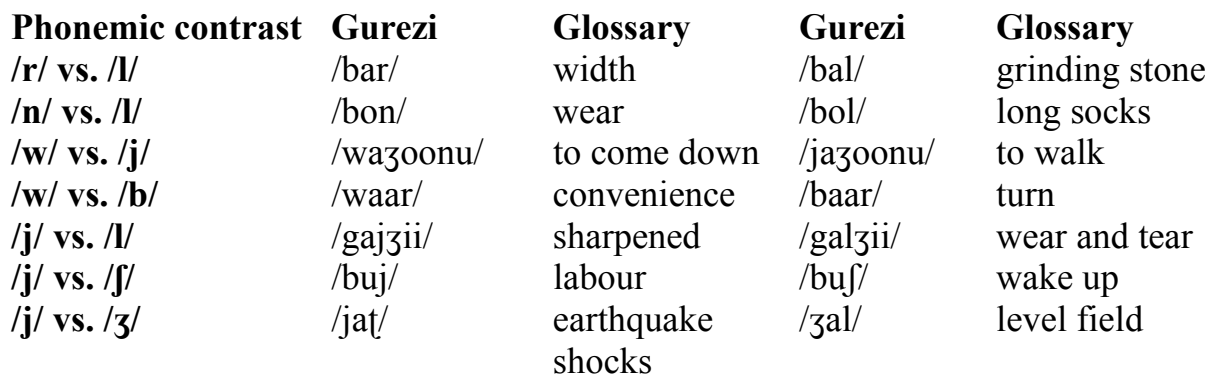

\subsubsection{Distribution of Nasals, Laterals and Glides}

The distribution of the nasal, lateral and glide consonant phonemes in initial, intervocalic and final positions is given below: 


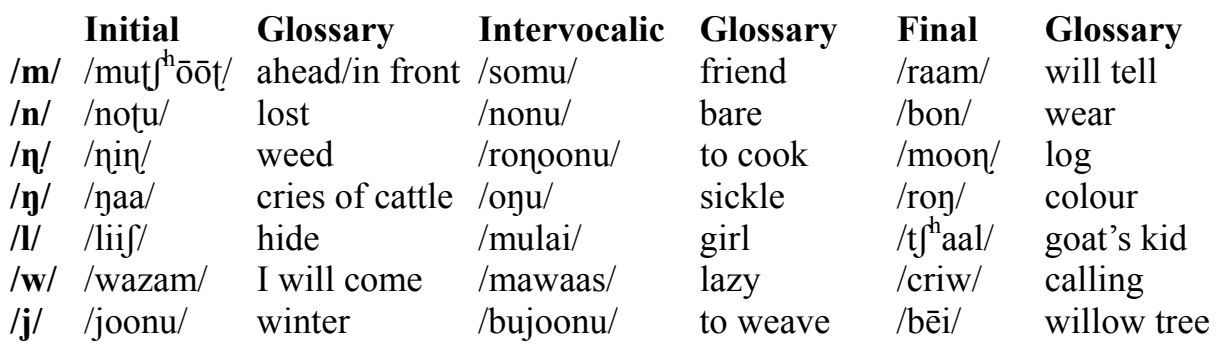

\section{Ultra Short Vowels}

The database for the present study shows the presence of very short vowels in some contexts. In these cases, sometimes there seems to be no vowel present, but sometimes a very short vowel is pronounced. These vowels are present in word final position following a plosive or a nasal. Consider the following examples:

$\begin{array}{ll}\text { Gurezi } & \text { Glossary } \\ \text { /noti/ } & \text { nose } \\ \text { /jazoonu/ } & \text { to walk } \\ \text { /wajoonu/ } & \text { to open } \\ \text { /phiini/ } & \text { water current } \\ \text { /bati/ } & \text { stone }\end{array}$

These ultra short vowels may be associated with the release of the obstruction associated with the nasal or plosive. Most of the verbs in the infinitive form having the suffix /oonu/ seem to have this short vowel. However, since these do not form minimal pair of words, they have been treated together with the short vowels.

\section{Pitch Accent}

Shina has been defined as a pitch accented language. The observation that Shina is a pitch accented language has been made with reference to Gilgiti (Bailey 1924; Radloff 1999), Kohistani (Schmidt-Kohistani 2008) and Palula (Liljegren 2008) varieties. It means that every word in these varieties of Shina has one syllable that is accented or prominent in comparison to the rest of the syllables. This is true of all the grammatical categories of words (Radloff 1999, p. 57).

In Shina accent is carried by both short and long vowels. In syllables with long vowels the accent is carried by either the first part ${ }^{5}$ of the vowel or the second part (Radloff 1999, p. 58).

${ }^{5}$ Syllables have generally been categorised into heavy and light as an indication of their weight. Syllables having a long vowel and/or a coda are considered as heavy syllables, while syllables 
The data collected for the present study indicate that pitch accent in Gurezi Shina behaves in the same manner as in Gilgiti, Kohistani and Palula. Every word in Gurezi has one and only one accented syllable, irrespective of whether the word is monosyllabic or polysyllabic. Complex words comprising a root morpheme and one or more suffixes can have the accented syllable either in its root morpheme or the affixed morpheme. Thus, similarly to other varieties of Shina, pitch accent in Gurezi is a lexical feature.

Accent in Gurezi much like in Gilgiti Shina, as reported by Radloff (1999, pp. 57-63), is reflected as high pitch and lack of accent as absence of pitch. This high pitch is always local, relative to the other syllables of the word and is unaffected by normal declination over the course of an utterance. However, the high pitch of the accented syllable may not be seen as a level pitch, rather there is always a kind of associated contour. It may be a rise from an unaccented syllable to an accented one or a fall from an accented syllable to an unaccented one. Like other varieties of Shina, it has been found in Gurezi that syllables having a long vowel always carry the accent, irrespective of their position in a word.

As already stated, in Gurezi like in other varieties of Shina, a long vowel always attracts accent and this can be placed on either of the two moras.

Consider the pitch accent in the following words; the vowel/mora with the superscript /'/ indicates the accent.

$\begin{array}{llll}\text { Gurezi } & \text { Glossary } & \text { Gurezi } & \text { Glossary } \\ \text { /záa/ } & \text { brother } & \text { /mújal/ } & \text { earthquake } \\ \text { /sií/ } & \text { beautiful } & \text { /1iji/ } & \text { air } \\ \text { /ázu/ } & \text { clouds } & / \text { juún/ } & \text { moon } \\ \text { /páaj/ } & \text { cave } & \text { /ajịp/ } & \text { horse } \\ \text { /hanoó/ } & \text { egg } & / \mathrm{th} \text { 'ímu/ } & \text { fish } \\ \text { /boón/ } & \text { utensils } & \text { /ánu/ } & \text { this }\end{array}$

\section{Pitch Accent Contrast in Minimal Pairs}

In the following some minimal pair of words, contrasted by pitch accent, are presented. In each of the word pairs the phonological structure of the two words is identical, and the different meanings are designated only by the placement of pitch accent.

$\begin{array}{llll}\text { Gurezi } & \text { Glossary } & \text { Gurezi } & \text { Glossary } \\ \text { /Sílu/ } & \text { a wild vegetable } & \text { /Siilu/ } & \text { loose } \\ \text { /daál/ } & \text { ashes } & \text { /dáal/ } & \text { carefree walk }\end{array}$

having only a short vowel are treated as light. Syllable weight has been explained in terms of the weight bearing units called mora. A short vowel is considered to be one mora and a long vowel two moras. A coda following a short vowel in a syllable is also taken as one mora. However, this is only true for some languages; many languages treat CVC pattern as comprising a single mora. See Liljegren $(2008$, p. 74). 


$\begin{array}{llll}\text { /phaál/ } & \text { tip of ploughshare } & \text { /p áal/ } & \text { to initiate a marriage proposal } \\ \text { /sií/ } & \text { beautiful } & \text { /síi/ } & \text { sewed } \\ \text { /theén/ } & \text { a local tree } & \text { /téen/ } & \text { send (imp) } \\ \text { /baái/ } & \text { twelve } & \text { /báai/ } & \text { after recovery from illness } \\ \text { /lií/ } & \text { after cutting } & \text { /líi/ } & \text { addressing a girl } \\ \text { /laái/ } & \text { partial hiding } & \text { /láai/ } & \text { addressing an elder woman } \\ \text { /waái/ } & \text { expression of grief } & \text { /wáai/ } & \text { contraction of body muscles }\end{array}$

Figure 1 presents the pitch accent pattern of a minimal pair of words that are contrasted on the basis of pitch accent. In the figure read from left to right, the first pattern reflects the pitch accent in the word / $\mathrm{p}^{\mathrm{h}}$ aál/ that falls on the second mora of the long vowel. The next pattern is that of the word $/ \mathrm{p}^{\mathrm{h}}$ áal/ in which the pitch falls from the first mora to the second mora making the former accented.

\section{Gurezi Glossary \\ $/ \mathrm{p}^{\mathrm{h}}$ aál/ $\quad$ tip of ploughshare \\ Gurezi Glossary \\ $/ \mathrm{p}^{\mathrm{h}}$ áal/ $\quad$ to initiate a marriage proposal}

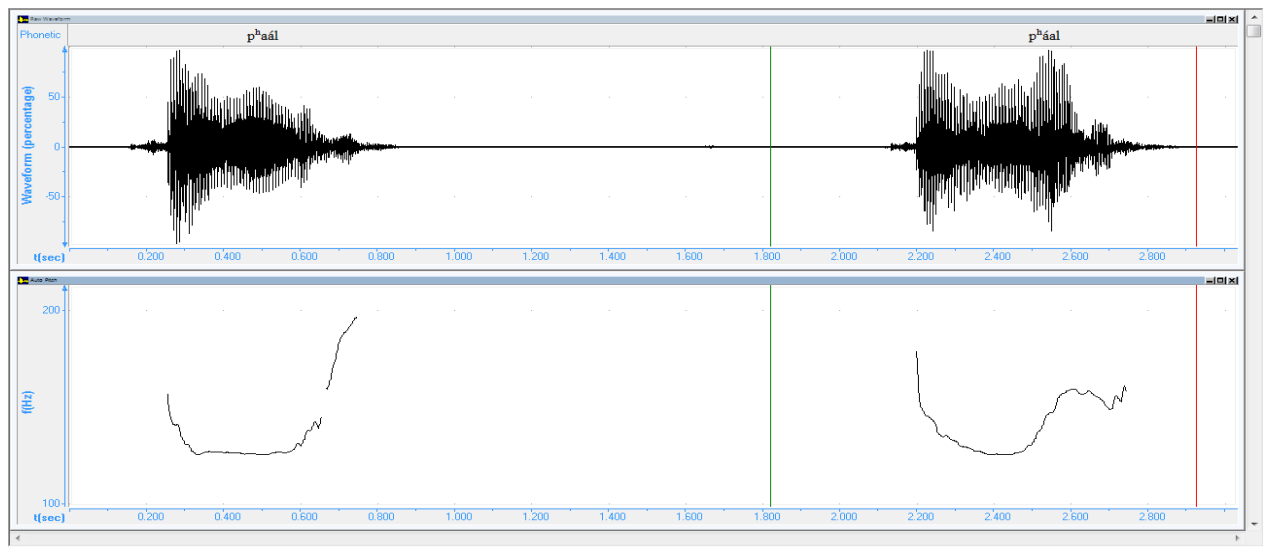

Figure 1

Pitch accent patterns compared / $\mathrm{p}^{\mathrm{h}}$ aál/ vs. / $\mathrm{p}^{\mathrm{h} a ́ a l}$ / 


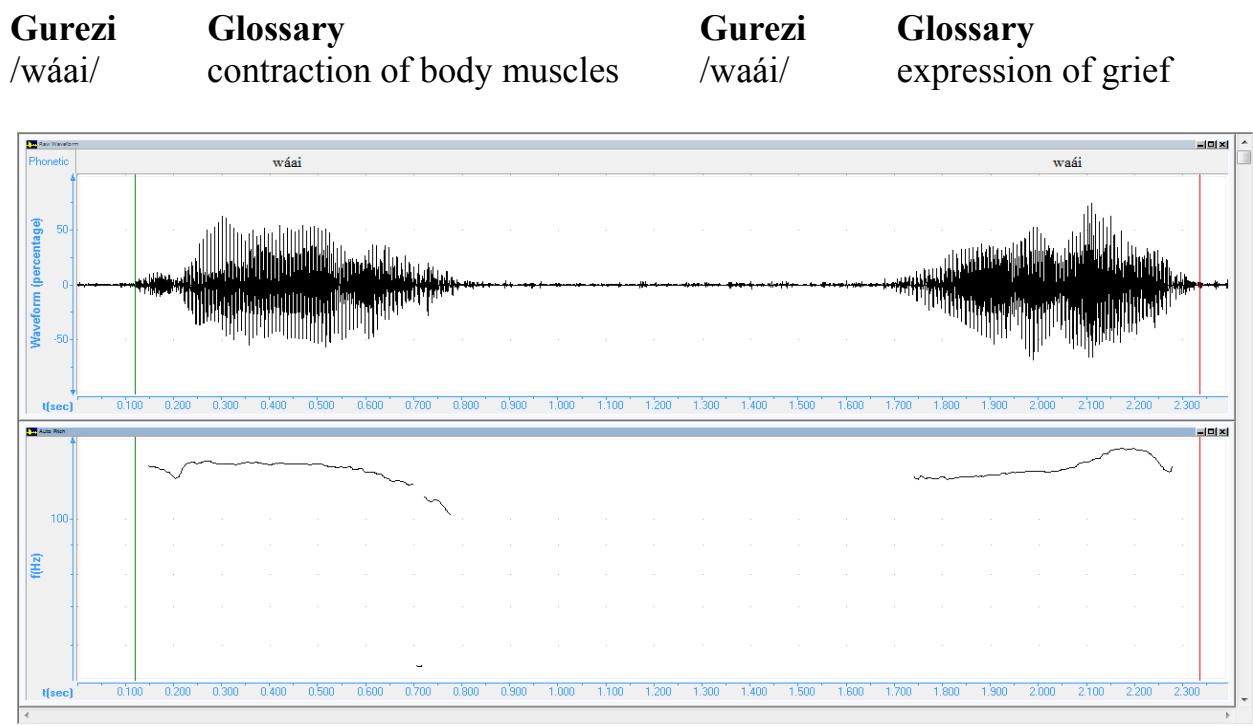

Figure 2

Pitch accent patterns compared /wáai/ vs. /waái/

Figure 2 also presents the graph of another minimal pair of words contrasted on the basis of pitch accent. In the figure read from left to right, the first pattern shows the pitch accent in the word /wáai/ carried by the first mora of the long vowel. The next pattern shows the pith accent on the second mora of the word /waái/.

\section{Bibliography}

Ahmed, M. - Ahmad, T. (2012): A Note on Kashmiri and Shina Phonology. Interdisciplinary Journal of Linguistics (IJL) (Srinagar, University of Kashmir) Vol. V, pp. 255-262.

Ahmed, M. - Ahmad, T. Shina (2014): In: Koul, O. N. (ed.): People's Linguistic Survey of India. Vol. 12: The Languages of Jammu and Kashmir. New Delhi, Orient Blackswan.

Bailey, T. G. (1924): Grammar of the Shina Language. London, Royal Asiatic Society.

Bailey, T. G. (1925): The Sounds of Shina. BSOS Vol. 3, No. 4, pp. 799-802.

Bashir, E. (2003): Dardic. In: Cardona, G. - Jain, D. (eds): The Indo-Aryan Languages. London, Routledge, pp. 818-894.

Fussmann, Gérard (1972): Atlas linguistique des parlers dardes et kafirs. Vol. 86. Paris, Publications de l'École Française d'Extrême-Orient.

Grierson, George Abraham (1919): Linguistic Survey of India. Vol. 8, Part 2: Specimens of the Dardic or Piśācha Languages (Including Kāshmīrī). Calcutta, Superintendent, Government Printing, India.

Kohistani, R. -Schmidt, R. L. (2006): Shina in Contemporary Pakistan. In: Saxena, Anju-Borin, Lars (eds): Trends in Linguistics: Lesser Known Languages of South Asia. Berlin, Mouton de Gruyter, pp. 138-160. 
Koul, O. N. - Schmidt, R. L. (1984): Dardistan Revisited: An Examination of the Relationship between Kashmiri and Shina. In: Koul, O. N.-Hook, P. (eds): Aspects of Kashmiri Linguistics. New Delhi, Bahri Publications, pp. 1-26.

Leitner, G. W. (1880): Kafiristan: Section 1. The Bashgali Kafirs and Their Language. Journal of the United Service Institute of India 43.

Leitner, G. W. (1893): The Hunza and Nagyr Handbook: Being an Introduction to a Knowledge of the Language, Race, and Countries of Hunza, Nagyr, and a Part of Yasin. Woking, Oriental University Institute.

Liljegren, H. (2008): Towards a Grammatical Description of Palula. An Indo-Aryan Language of the Hindu Kush (Doctoral Thesis in Linguistics). Stockholm, Stockholm University.

Masica, C. P. (1991): The Indo-Aryan Languages. Cambridge, Cambridge University Press.

Mock, John (1997): Dards, Dardistan, \& Dardic: An Ethnographic, Geographic, \& Linguistic conundrum. http://www.mock\&oneil.com./dard.html (accessed on 15th July 2012)

Morgenstierne, Georg (1926): Report on a Linguistic Mission to Afghanistan. Oslo, Instituttet for ammenlignende Kulturforskning (Serie C I-2).

Morgenstierne, Georg (1932): Report on a Linguistic Mission to North-Western India. Oslo, Instituttet for Sammenlignende Kulturforskning (Serie C III-1).

Morgenstierne, Georg (1961): Dardic and Kafir Languages. In: Lewis, B. - Pellat, Ch. - Schacht, J. (eds): The Encyclopaedia of Islam. New Edition, Vol. 2, Fasc. 25. Leiden, E. J. Brill, pp. $138-139$.

Petersen, J. Heegård (2006): Local Case-marking in Kalasha. Copenhagen, University of Copenhagen (Doctoral Thesis in Linguistics).

Radloff, C. F. (1992): The Dialects of Shina. In: Backstrom, P.-Radloff, C. (eds): Languages of Northern Areas: Sociolinguistic Survey of Northern Pakistan. Vol. 2. Islamabad, National Institute of Pakistan Studies and Summer Institute of Linguistics, pp. 89-203.

Radloff, C. F. (1999): Aspects of the Sound System of Gilgiti Shina. Islamabad, National Institute of Pakistan Studies and Summer Institute of Linguistics.

Rajapurohit, B. B. (1983): Shina Phonetic Reader. Mysore, Central Institute of Indian Languages.

Schmidt, R. L. - Kohistani, R. (1998): Paalus/kostyo/Shina Revisited. Acta Orientalia (Norway) Vol. 59, pp. 106-149.

Schmidt, R. L. - Kohistani, R. (2008): A Grammar of the Shina Language of Indus Kohistan. Wiesbaden, Harrassowitz Verlag.

Schmidt, R. L. - Kaul, V. K. (2008): A Comparative Analysis of Shina and Kashmiri Vocabularies. Acta Orientalia (Norway) Vol. 69, pp. 231-302.

Schmidt, R. L. - Kaul, V. K. (2010): A Grammatical Sketch of Guresi Shina. In: Karttunen, K. (ed.): Anantam Sastram: Indological and Linguistic Studies in Honour of Bertil Tikkanen (Studia Orientalia, 108). Helsinki, Finland Oriental Society, pp. 195-214.

Strand, R. F. (1973): Notes on the Nuristani and Dardic Languages. JAOS Vol. 93, No. 3, pp. $297-$ 305.

Strand, R. F. (2001): Indo-Aryan-Speaking Peoples of Hindu-Kush Regions. http://nuristan.info/ IndoAryan/IndoAryas.html (accessed 23rd January 2014).

Trail, R. L. (1999): Kalasha Dictionary - with English \& Urdu. Islamabad, National Institute of Pakistan Studies and Summer Institute of Linguistics.

Wilson, J. (1899): On the Gurezi Dialect of Shina. The Indian Antiquary Vol. 28, pp. 93-102.

Zoller, C. P. (2005): A Grammar and Dictionary of Indus Kohistani. Vol. 2. The Hague, Mouton. 